See Article page 39.

\section{Commentary: In the absence of convincing evidence, more is not better}

\author{
Matheus P. Falasa, MD, George J. Arnaoutakis, MD, \\ and Thomas M. Beaver, MD, MPH
}

In this issue of the Journal, Anzai and colleagues ${ }^{1}$ provide an excellent review of the evidence concerning whether patients undergoing bicuspid aortic valve replacement require aortic hemiarch replacement in the absence of aneurysmal dilation. The authors describe the hemodynamic theory of aortic aneurysm formation in patients with a bicuspid aortic valve, as well as the genetically-linked differences in matrix metalloproteinase production and elastin distribution noted in this patient group.

At high-volume aortic centers, the safety of concomitant hemiarch replacement in patients undergoing aortic root replacement is well known. Previous studies have demonstrated a more aggressive surgical approach with respect to the aortic arch is not linked to significantly worse outcomes. $^{2-4}$ Although the safety of a more aggressive surgical approach to the ascending aorta in patients with a bicuspid aortic valve has been reported, the question of its necessity remains unresolved. The authors cite studies that followed bicuspid aortic valve patients at a mean 4- to 5-year follow up after aortic valve and ascending aortic replacement. ${ }^{2,5-8}$ None of these studies demonstrated instances of reoperation for aneurysmal degeneration when abiding by a more conservative surgical approach.

These studies represent hundreds of patients across multiple centers. However, a 5-year follow up may be insufficient to capture long-term aneurysmal degeneration in this population. Indeed, an Italian study that followed 50 bicuspid aortic valve patients for a mean of 234 months after isolated

From the Division of Thoracic and Cardiovascular Surgery, Department of Surgery, University of Florida, Gainesville, Fla.

Disclosures: The authors reported no conflicts of interest.

The Journal policy requires editors and reviewers to disclose conflicts of interest and to decline handling or reviewing manuscripts for which they may have a conflict of interest. The editors and reviewers of this article have no conflicts of interest.

Received for publication Dec 29, 2020; revisions received Dec 29, 2020; accepted for publication Dec 30, 2020; available ahead of print Jan 28, 2021.

Address for reprints: Thomas M. Beaver, MD, MPH, Division of Thoracic and Cardiovascular Surgery, University of Florida, PO Box 100129, Gainesville, FL 32610 (E-mail: Thomas.Beaver@surgery.ufl.edu).

JTCVS Open 2021;5:44-5

2666-2736

Copyright $(2020$ The Authors. Published by Elsevier Inc. on behalf of The American Association for Thoracic Surgery. This is an open access article under the CC BY-NCND license (http://creativecommons.org/licenses/by-nc-nd/4.0/).

https://doi.org/10.1016/j.xjon.2020.12.017
Check for updates

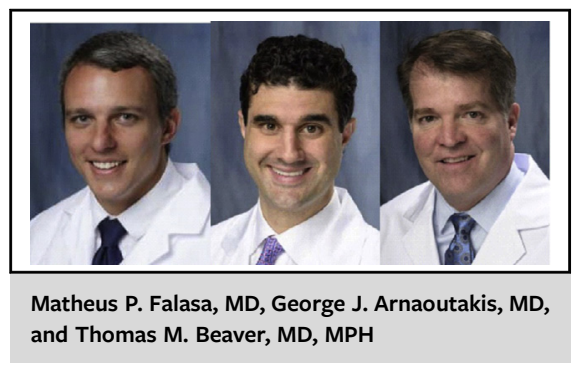

CENTRAL MESSAGE

Current evidence, limited by

follow-up duration, does not

support replacement of a nona-

neurysmal aortic arch in bicuspid

aortic valve patients

aortic valve replacement found that 3 patients required late intervention for aneurysm of the ascending aorta, one each at 36,120 , and 264 months. In a population with mean age of 55 to 60 in most studies, a 5-year follow-up may be insufficient to capture reintervention events. However, these cumulative studies provide the only available insight into aneurysmal degeneration in bicuspid aortic valve patients. We agree with the authors' conclusion that aggressive hemiarch replacement is not indicated in the absence of significant aneurysmal enlargement of the ascending aorta.

The authors present the hemodynamic theory of aneurysmal degeneration in bicuspid aortic valve patients, as well as work by Chim and colleagues ${ }^{9}$ demonstrating histopathologic differences between idiopathic aneurysmal dilation and aneurysmal dilation associated with bicuspid aortic valve. Recent genetic discoveries, such as the association between bicuspid aortic valve and a mutation in the NOTCH1 gene, ${ }^{10}$ have opened the door for additional predictors of aneurysmal degeneration in this population. Current evidence steers us away from hemiarch repair in bicuspid aortic valve patients without dilation of the arch; however, perhaps in the future such factors as detailed aortic anatomy, point-of-care tissue testing, and genetic analysis will guide a personalized approach to dictate the extent of aortic replacement performed in these patients.

\section{References}

1. Anzai I, Kriegel J, Kim I, Pearsall C, Lewis M, Rosenbaum M, et al. Should all patients with aortic aneurysm and bicuspid aortic valve also undergo hemiarch? J Thorac Cardiovasc Surg Open. 2021;5:39-43.

2. Greason KL, Crestanello JA, King KS, Bagameri G, Cicek SM, Stulak JM, et al. Open hemiarch versus clamped ascending aorta replacement for aortopathy during initial bicuspid aortic valve replacement. J Thorac Cardiovasc Surg. 2019; 161:12-20.e2. 
3. Sultan I, Bianco V, Yazji I, Kilic A, Dufendach K, Cardounel A, et al. Hemiarch reconstruction versus clamped aortic anastomosis for concomitant ascending aortic aneurysm. Ann Thorac Surg. 2018;106:750-6.

4. Malaisrie SC, Duncan BF, Mehta CK, Badiwala MV, Rinewalt D, Kruse J, et al. The addition of hemiarch replacement to aortic root surgery does not affect safety. J Thorac Cardiovasc Surg. 2015;150:118-24.e2.

5. Bilkhu R, Youssefi P, Soppa G, Sharma R, Edsell M, Jahanjiri M, et al. Fate of the aortic arch following surgery on the aortic root and ascending aorta in bicuspid aortic valve. Ann Thorac Surg. 2018;106:771-6.

6. Iribarne A, Keenan J, Benrashid E, Wang H, Meza JM, Ganapathi A, et al. Imaging surveillance after proximal aortic operations: is it necessary? Ann Thorac Surg. 2017;103:734-41.

7. Abdulkareem N, Soppa G, Jones S, Valencia O, Smelt J, Jahangiri M. Dilatation of the remaining aorta after aortic valve or aortic root replacement in patients with bicuspid aortic valve: a 5-year follow-up. Ann Thorac Surg. 2013;96:43-9.

8. Park CB, Greason KL, Suri RM, Michelena HI, Schaff HV, Sundt TM. Should the proximal arch be routinely replaced in patients with bicuspid aortic valve disease and ascending aortic aneurysm? J Thorac Cardiovasc Surg. 2011; 142:602-7.

9. Chim YH, Davies HA, Mason D, Nawaytou O, Field M, Madine J, et al. Bicuspid valve aortopathy is associated with distinct patterns of matrix degradation. $J$ Thorac Cardiovasc Surg. 2020;160:e239-57.

10. Jiao J, Tian W, Qiu P, Norton EL, Wang MM, Chen YE, et al. Induced pluripotent stem cells with NOTCH1 gene mutation show impaired differentiation into smooth muscle and endothelial cells: implications for bicuspid aortic valve-related aortopathy. J Thorac Cardiovasc Surg. 2018;156: 515-22.e1. 